whole, though the rear part radiating out behind the curved frontage might be of the relatively cheap design favoured by Prof. Oliphant. The financial stringency indicated in the resolution of the Council is due to the heavy expenditure required for the completion and equipment of the new Medical School. The needs of the University of Birmingham, particularly in such a subject as physics, should have a first call on the generosity of Midland industrialists.

\section{Protection of Wild Fowl}

THE Wild Fowl Enquiry Sub-committee of the British Section of the International Committee for Bird Protection was received on April 6 by Sir Samuel Hoare, the Home Secretary, to discuss the question of the further protection of wild fowl. The deputation, which was introduced by $\mathbf{M r}$. Perch $\mathbf{R}$. Lowe, chairman of the sub-committee, included its secretary, Miss P. Barclay-Smith, and representatives of bodies interested in the preservation of wild life and of museums. The immediate object which this sub-committee has in view is to promote legislation aimed at the prevention of the importation of wild duck and wild geese into Great Britain during the close season. There is also the further question of preventing the exposure for sale of wild duck during the same period and also of extending the close season to such limits as would be in the interests of the wild duck, sportsmen, and everyone concerned. At the present moment, large consignments of wild duck are shipped from Holland to British markets during our close time, having been caught in the many decoys which that country possesses. In view of the threatened diminution of the status of wild duck brought about by the many adverse factors affecting their welfare at the present time, the commercialization in Europe of any bird. habitually shot for either sport or food, or both, cannot rationally be allowed to continue during both the open and close season. It will be remembered that the present sub-committee was successful last year in getting legislation set up to prevent the importation of quail into Great Britain during the close time.

\section{Royal Botanic Garden, Calcutta}

A NUMBER of men of science from Great Britain and elsewhere who were attending the jubilee meeting of the Indian Science Congress in January last were able to be present at the celebrations of the hundred and fiftieth anniversary of the Royal Botanic Garden, Sibpur, Calcutta, a note on the history of which appeared in NATURE of January 1. Sir James Jeans, president of the Congress, congratulated the Garden on its anniversary. Sir Arthur Hill, director of the Royal Botanic Gardens, Kew, in his address, stated that it was the first time a director of the Royal Botanic Gardens, Kew, had been to India in his official capacity. Sir Arthur pointed out the similarity in position, scientific interest and rsthetic beauty between the two Gardens. He emphasized the importance of the Sibpur Garden, and expressed the hope that the Government of Bengal will recognize its importance and that the necessary funds will be forthcoming both for the maintenance of the scientific staff and for the upkeep of the living collections. Sir Arthur suggested that Sibpur should, like Kew, serve as a training ground for student gardeners, in order that the many good gardens and parks in India may be maintained at a high standard of excellence. To this end, he suggested that the practice of sending men from Kew to Sibpur as instructors or curators should be continued.

DR. K. Biswas, the present superintendent of the Royal Botanic Garden, Sibpur, referred to the keen interest taken in its welfare by the late Sir Jagadis Chandra Bose, and also by the late Prof. Hans Molisch, both of whom frequently visited the Garden. Dr. Biswas briefly reviewed the history of the Garden, most of the superintendents of which have been botanists of eminence. Economic botany naturally takes first place in the activities of its scientific staff, and Dr. Biswas gave examples of what has been and is being done in this direction, for example, cultivation and utilization of teak, jute, cotton, flax, tobacco, rubber, coffee, cocoa, etc. The Garden also offers good scope for the study of the tropical flora; 1,500 species are under cultivation. In fact, Indian botany is offered excellent opportunity for advancement with the help of the Royal Botanic Garden, its excellent Herbarium and its Library at Sibpur, Calcutta.

\section{British Empire Cancer Campaign}

AT the recent quarterly meeting of the Grand Council of the British Empire Cancer Campaign, a further grant of $£ 1,000$ for one year was placed at the disposal of the North of England Council of the Campaign to enable the short wave investigations to be continued under the direction of Dr. F. Dickens and Dr. S. F. Evans. This work, which is a continuation of that which appeared in the last Annual Report of the Campaign and in a recent issue of the American Journal of Cancer, concerns the investigations of the effect of varying forms of heat upon malignant tissues. It was also decided to allot a further sum of $£ 1,338$ for one year for the extension of the national propaganda work being carried out by the Central Propaganda Committee. Sir Charles Gordon-Watson, vice-chairman of the Clinical Cancer Research Com. mittee, reported that the organization for the statistical cancer inquiries in the teaching and special hospitals of London and the hospitals of the London County Council and the Middlesex County Council has now been completed. He stated that all these Institutions have appointed registrars to take charge of the records at their respective hospitals and that the headquarters' arrangements are being perfected to deal with the data concerning more than 17,000 new cases of cancer yearly in the metropolitan area of London. The Grand Council confirmed the recommendation for the appointment in the near future of a full-time medical secretary and registrar at headquarters for this purpose. 